\title{
Dosen Impian: Analisis Persepsi Mahasiswa Pendidikan Guru Sekolah Dasar Universitas Mataram
}

\author{
Itsna Oktaviyanti ${ }^{1}$, Tika Puspa Pandini ${ }^{2}$, Zul Hijjayati ${ }^{3)}$, Sismunilawati ${ }^{4)}$ \\ ${ }^{1)}$ Fakultas Keguruan dan Ilmu Pendidikan, Universitas Mataram \\ *Corresponding author E-mail: itsna@unram.ac.id
}

\begin{abstract}
Abstrak
Keywords: Dosen, Impian, Mahasiswa, PGSD

Dosen merupakan salah satu faktor penting dalam rangka mewujudkan pembelajaran yang menyenangkan. Akan tetapi banyak mahasiswa yang mengeluh mengenai kinerja dosen yang tidak sesuai dengan pandangannya tentang gambaran seorang dosen yang ideal. Sehingga hal tersebut berdampak pada menurunnya minat dan motivasi belajar mahasiswa. Penelitian ini bertujuan untuk mengetahui perspektif mahasiswa mengenai kriteria dosen yang diimpikan, sehingga bisa menjadi acuan untuk dosen agar menjadi dosen yang diidamkan oleh mahasiswa. Metode penelitian yang digunakan adalah metode survey dengan menggunakan pendekatan kualitatif. Lokasi penelitian di Kampus II Universitas Mataram, subyek pada penelitian ini adalah mahasiswa PGSD semester tiga. Teknik pengumpulan data yang digunakan adalah kuesioner dengan instrumennya berupa pertanyaan-pertanyaan yang diberikan kepada responden. Kuesioner disebarkan kepada 50 responden (mahasiswa PGSD semester 3). Hasil penelitian menunjukan bahwa kriteria dosen yang diimpikan mahasiswa, yaitu (1) dosen yang terampil dalam melakukan penilaian, (2) dosen yang disiplin waktu, (3) dosen yang menyenangkan, (4) dosen yang memiliki keterampilan mengajar, (5) dosen inspiratif, (6) dosen yang memiliki good rapport, dan (7) dosen yang menerima pendapat mahasiswa.
\end{abstract}

Keywords: Dosen, Impian, Mahasiswa.

\section{Abstract}

Keywords: Lecturer, Dream, Student
Lecturers are one of the important factors in order to realize enjoyable learning. However, many students complained about the lecturers' performance which was not in accordance with their view of an ideal lecturer description. So that it has an impact on decreasing student interest and learning motivation. This study aims to determine the perspective of students regarding the criteria of dreamed lecturers, so that they can become a reference for lecturers to become lecturers desirable by students. The research method used was a survey method using a qualitative approach. Location of the research at Campus II of the University of Mataram, the subjects of this study were the third semester PGSD students. The data collection technique used was a questionnaire with the instrument in the form of questions given to respondents. The questionnaire was distributed to 50 respondents (semester 3 PGSD students). The results showed that the criteria of lecturers dreamed of by students, namely (1) lecturers who are skilled in conducting assessments, (2) lecturers who are disciplined by time, (3) pleasant lecturers, (4) lecturers who have teaching skills, (5) inspirational lecturers , (6) lecturers who have good rapport, and (7) lecturers who accept student opinions.

Keywords: Lecturer, Dream, Student. 


\section{Pendahuluan}

Undang-Undang No. 20 tahun 2003 pasal 3 menegaskan bahwa Pendidikan Nasional berfungsi mengembangkan kemampuan dan membentuk watak serta peradaban bangsa yang bermartabat dalam rangka mencerdaskan kehidupan bangsa, bertujuan untuk berkembangnya potensi peserta didik agar menjadi manusia yang beriman dan bertakwa kepada Tuhan Yang Maha Esa, berakhlak mulia, sehat, berilmu, cakap, kreatif, mandiri dan menjadi warga negara yang demokratis serta bertanggung jawab.

Dalam upaya mewujudkan tujuan pendidikan tersebut, proses pembelajaran memegang peranan penting, karena melalui proses inilah tujuan pendidikan akan tercapai dalam bentuk perubahan perilaku peserta didik (Slameto, 2015). Salah satu pihak yang menentukan berhasil tidaknya proses pembelajaran dalam mencapai tujuan pendidikan adalah pendidik dalam hal ini dosen. Dosen dalam proses pembelajaran di bangku perkuliahan menempatkan kedudukan sebagai figure central. Meskipun central, dosen tidak dapat mewujudkan tujuan pendidikan sendiri, harus mendapat dukungan penuh dari mahasiswa. Setidaknya ada 3 unsur yang harus ada dalam proses belajar mengajar, yaitu mahasiswa mengembangkan dirinya seoptimal mungkin melalui berbagai kegiatan belajar sesuai dengan karakteristiknya, dosen mengusahakan terciptanya situasi pembelajaran yang bermakna sehingga tercipta pengalaman belajar, dan tujuan yaitu sesuatu yang diharapkan setelah adanya kegiatan belajar. Dengan demikian proses pembelajaran dapat diartikan sebagai suatu rangkaian interaksi antara mahasiswa dan dosen dalam rangka untuk mencapai tujuan (Syamsudin, 2007).

\section{Menurut Undang-Undang Republik}

Indonesia Nomor 14 Tahun 2005 tentang Guru dan dosen, bahwa dosen adalah pendidik profesional dan ilmuan dengan tugas utama menstransformasikan, mengembangkan, dan menyebarluaskan ilmu pengetahuan, teknologi, dan seni melalui pendidikan, penelitian, dan pengabdian kepada masyarakat. Dosen memiliki banyak tugas, sehingga dosen wajib mengusai empat kompetensi yaitu kompetensi pedagogik, professional, kepribadian dan sosial. Kompetensi pedagoik tercermin pada kemampuan merancang dan melaksanakan proses pembelajaran yang dapat merangsang mahasiswa untuk belajar, sedangkan kompetensi professional yang tercermin dari penguasaan materi kuliah. Kemudian kompetensi kepribadian tampak dari bagaimana dosen bersikap dan bertutur kata yang baik sehingga dapat menjadi contoh bagi mahasiswanya, meskipun demikian dosen juga perlu menguasai komoetensi sosial agar dapat mengkomunikasikan pemikirannya dengan baik dan jelas.

Dalam proses belajar mengajar dosen merupakan salah satu faktor penting dalam rangka mewujudkan pembelajaran yang menyenangkan. Akan tetapi banyak mahasiswa yang mengeluh mengenai kinerja dosen yang tidak sesuai dengan pandangannya tentang gambaran seorang dosen yang ideal, dimana dosen dianggap tidak dapat memotivasi minat belajar mahasiswanya. Mahasiswa akan 
semangat belajar apabila diajar oleh dosen yang menurut mereka itu menyenangkan.

Setiap mahasiswa memiliki persepsi yang berbeda mengenai kriteria dosen impian atau ideal. Dosen ideal adalah dosen yang mampu membuat siswa menikmati kegiatan belajar di kelas. Selain itu, ia juga mampu menjadi teladan bagi mahasiswanya. Hal tersebut dapat tercermin dari cara bicaranya yang menyejukkan hati, ilmu yang disampaikan bermanfaat, dan kehadirannya membuat para mahasiswa merasa belajar menjadi menyenangkan. Hal tersebut dapat membuat mahasiswa betah berada di kelas untuk menerima materi kuliah.

Menjadi seorang dosen yang baik dan diidolakan oleh mahasiswa bukan hal yang mudah, terlebih lagi jika dapat menarik perhatian mahasiswa. Pada dasarnya sifat mahasiswa itu berbeda-beda, hal itulah yang menjadi masalah yang harus diatasi oleh semua dosen dalam memilih metode agar dapat membuat nyaman semua mahasiswa. Dibutuhkan kesabaran yang ekstra, dan cara-cara tersendiri bagi dosen agar disukai mahasiswanya.

Penelitian ini bertujuan untuk mengetahui perspektif mahasiswa mengenai kriteria dosen yang diimpikan, sehingga bisa menjadi acuan untuk dosen dalam melaksanakan tugasnya

\section{Metode}

Metode penelitian yang digunakan dalam penelitian ini adalah metode survey. Metode survey adalah sebuah teknik riset atau penelitian yang bertujuan untuk mendapatkan data yang valid dengan memberi batas yang jelas atas data kepada suatu obyek tertentu. Bentuk penelitian ini adalah penelitian kualitatif.

Lokasi penelitian dilakukan di Kampus 2 Universitas Mataram, Jl. Brawijaya No. 22, Cakranegara Selatan, Kecamatan Cakranegara, Kota Mataram, Nusa Tenggara Barat. Penelitian ini dilakukan mulai tanggal 2 Desember 2019 sampai dengan tanggal 7 Desember 2019. Subyek pada penelitian ini adalah Mahasiswa PGSD semester 3 (tiga). Teknik pengumpulan data yang digunakan adalah kuesioner, dengan instrumen berupa pertanyaan-pertanyaan yang diberikan kepada responden. Kuesioner disebarkan kepada 50 responden (mahasiswa PGSD semester 3). Teknik analisis data menggunakan teknik analisis data kualitatif

\section{Hasil dan Pembahasan}

Dosen dalam kegiatan pembelajaran akan selalu diamati, diperhatikan, didengar, dan ditiru bahkan dinilai oleh mahasiswanya seperti penampilannya di kelas, karakternya, kemampuannya menguasai materi pelajaran, kemampuan mengajar, perhatian terhadap mahasiswa, hubungan antara dosen dan mahasiswa, sikap dan tingkah lakunya selama kegiatan pembelajaran berlangsung. Hal tersebut mendorong dosen agar bisa menjadi sosok yang ideal bagi mahasiswanya, adapun menurut hasil penelitiaan mengenai kriteria dosen impian 
mahasiswa yang diajukan responden dapat dibagi menjadi 7 kriteria, sebagai berikut.

\section{Terampil Melakukan Penilaian}

Penilaian merupakan salah satu hal yang penting dalam perkuliahan. Oleh sebab itu, mahasiswa menginginkan dosen yang terampil dalam melakukan penilaian. Menurut responden kriteria dosen yang terampil dalam melakukan penilaian adalah dosen yang melakukan penilaian secara objektif dan adil, serta dosen yang tidak pelit nilai dan pengertian.

Menurut Permendikbud Nomor 66 Tahun 2013 tentang Standar Penilaian Pendidikan, penilaian objektif adalah penilaian berbasis pada standar dan tidak dipengaruhi faktor subjektivitas. Sedangkan penilaian adil adalah penilaian yang tidak merugikan atau menguntungkan peserta didik berdasarkan latar belakang sosial, ekonomi, budaya, agama, bahasa, suku bangsa, warna kulit dan gender.

Hasil penelitian yang dilihat dari pendapat para responden mengenai kriteria dosen yang terampil melakukan penilaian tampak tidak konsisten, hal tersebut berkaitan dengan keprofesionalan seorang dosen. Disatu sisi, mahasiswa mengharapkan dosen dalam memberikan nilai harus objektif dan adil, ini berarti mahasiswa menginginkan para dosen melakukan penilaian sebagaimana mestinya atau apa adanya. Akan tetapi dipihak lain, mahasiswa menginginkan dosen untuk tidak pelit dalam memberikan nilai, yang lebih merukuk pada penilain secara subjektif.

Dari hasil tersebut, di harapkan para dosen dalam melakukan penilaian harus memperhatikan kepuasan mahasiswa. Kepuasan yang dimaksud adalah sesuai dengan kemampuan mahasiswa tanpa menyingkirkan hati nurani. Ada banyak kriteria yang dapat dijadikan acuan bagi dosen dalam menilai mahasiswa, hal tersebut harus sesuai dengan kontrak perkuliahan yang telah disepakati pada pertemuan awal.

\section{Dosen yang Disiplin Waktu}

Waktu merupakan suatu hal yang paling berharga dalam hidup manusia, tetapi seringkali disepelekan dan dianggap remeh. Ada banyak mahasiswa yang tidak dapat memanfaatkan waktunya dengan baik dalam menjalankan kewajibannya sebagai mahasiswa. Hal tersebut tidak hanya terjadi pada mahasiswa, terkadang seorang dosenpun lalai dalam menjalankan kewajibannya, hal tersebut secara tidak langsung menunjukan bahwa rendahnya kedisiplinan waktu yang dimiliki dosen.

Menurut Siswanto (2005: 291), disiplin adalah suatu sikap menghormati, menghargai, patuh, dan taat terhadap peraturan-peraturan yang berlaku, baik yang tertulis serta sanggup menjalankannya dan tidak mengelak untuk menerima sanksisanksinya apabila ia melanggar tugas dan 
wewenang yang diberikannya. Displin juga watak khas bagi setiap dosen ini bisa diartikan sebagai sikap patuh terhadap mencerminkan etos kerja masing-masing sesuatu.

dosen dalam pelaksanaan pembelajaran.

Kedisiplinan dosen dapat dilihat dari Faktor pertama adalah aspek kompetensi berbagai aspek, salah satunya adalah disiplin dosen dalam penugasan materi perkuliahan waktu. Disiplin waktu ini mencakup dan sekaligus penugasan kelas, kemudian ketepatan waktu masuk kelas, ketepatan faktor kedua adalah kedisiplinan dosen waktu keluar kelas, ketepatan dalam jadwal perkuliahan, efektivitas pemanfaatan waktu untuk penyampaian materi kuliah dan lain sebagainya.

Salah satu kriteria dosen yang diimpikan mahasiswa adalah dosen yang disiplin. Dosen yang kerap bolos dalam perkuliahan, sering hadir terlambat dan selalu paling akhir menyetor nilai, dosen yang tidak memberikan keterangan jika berhalangan menghadiri perkuliahan, bukan merupakan tipe dosen yang diimpikan mahasiswa. Mahasiswa akan senang jika dosen dalam perkuliahan datang tepat waktu, menyetor nilai tepat waktu, selalu memberikan kepastian atas kehadirannya, tidak suka merubah jam perkuliahan yang sudah sesuai dengan kontrak perkuliahan di awal pembelajaran, jadwal UTS dan UAS harus sesuai dengan jadwal yang telah dibuat bukan malah mengganti jadwal tersebut sesuai dengan keinginannya.

Dalam sebuah penelitian studi etnografi : Etos Kerja Dosen STAIN Kendari (Nurdin, 2013) ditemukan bahwa kinerja dosen berpengaruh besar dalam pelaksanaan pembelajaran. Kinerja yang menjadi ciri dan dalam pelaksanaan pembelajaran di ruang perkuliahan maupun di luar ruang perkuliahan. Dari pernyataan tersebut dapat disimpulkan bahwa kedisiplinan dosen menjadi faktor yang berpengaruh terhadap pelaksanaan pembelajaran, semakin disiplin dosen maka pelaksanaan pembelajaran akan menjadi semakin baik, itulah dosen impian mahasiswa.

\section{Dosen Yang Menyenangkan}

Salah satu kriteria dosen yang diimpikan mahasiswa adalah dosen yang menyenangkan. Dosen yang menyenangkan dalam artian dosen yang mampu menciptakan pembelajaran yang menyenangkan, tidak membosankan (monoton), humoris dan yang paling utama tidak membuat tegang mahasiswa.

Salah satu karakteristik dosen yang menyenangkan adalah humoris. Supriadi (2012: 3) mengungkapkan bahwa rasa humor dalam kelas merupakan cara untuk mengurangi kejenuhan dalam belajar. Maka dari itu, seorang dosen juga harus benar-benar mengetahui kondisi dari situasi dalam kelas sehingga dosen mampu menciptakan pembelajaran yang menyenangkan. 
Menurut Rudiana (Jumwaniyah, 2018: 93) karakter guru yang menyenangkan adalah guru yang mampu menciptakan kondisi pembelajaran yang nyaman, efektif dan menyenangkan bagi peserta didik untuk belajar dengan cara mengawali pembelajaran dengan senyum, menyampaikan materi dengan metode yang variatif, menyelipkan humor disela-sela pembelajaran, melibatkan peserta didik dalam diskusi, memberikan pujian pada setiap komentar yang diajukan peserta didik, memberikan kalimat-kalimat positif yang dapat meningkatkan motivasi peserta didik. Hal tersebut juga perlu dilakukan dosen untuk membuat proses perkuliahan menjadi menyenangkan bagi mahasiswa. Mahasiswa tidak menyukai dosen yang menciptakan suasana tegang, terlebih dosen yang seringkali meluapkan emosinya dihadapan mahasiswa atau sering disebut dosen killer. Mahasiswa lebih menyukai dosen yang ramah, murah senyum, dan bisa mengontrol emosinya dihadapan mahasiswa. Hal tersebut dikarenakan ketika suasana tegang dapat berpengaruh pada turunnya minat belajar mahasiswa. Oleh karena itu, dosen dituntut untuk bisa menciptakan suasana pembelajaran yang menyenangkan, hangat, dan santai.

\section{Memiliki Keterampilan Mengajar}

Kriteria lain menentukan dosen impian adalah keterampilan mengajar. Dalam menjelaskan konsep atau materi, seharusnya dosen membuat mahasiswa cepat mengerti, tidak bertele-tele, singkat, padat, dan jelas dalam artian dosen harus mempunyai keterampilan dalam mengajar serta mengutamakan efektifitas dan efisiensi.
Menurut Suryabrata (2014: 233), ada dua faktor yang mempengaruhi tinggi rendahnya prestasi belajar seseorang, yaitu faktor internal dan eksternal. Faktor internal adalah faktor dari dalam diri individu yang belajar, sedangkan faktor eksternal adalah faktor yang terdiri dari fakor lingkungan dan faktor instrumental. Hal tersebut menunjukkan keberagaman faktor yang mempengaruhi prestasi belajar, namun hasil temuan penelitian Prayitno (dalam Nasution 2001: 40) menyatakan bahwa kesuksesan belajar seseorang lebih banyak ditentukan oleh prasyarat penguasaan materi, keterampilan belajar, sarana belajar, kondisi pribadi dan lingkungan belajar, daripada proses belajar mengajar yang dilakukan guru/dosen di kelas. Dalam penelitian tersebut ditemukan bahwa metode mengajar dosen memberikan sumbangan yang besar/ pengaruh terhadap indeks prestasi mahasiswa dan lebih berpengaruh daripada faktor internal serta sarana belajar, lingkungan belajar maupun keterampilan belajar mahasiswa. Hal tersebut diperkuat oleh pernyataan Umar bahwa keberhasilan pendidikan terletak pada tenaga pengajar atau dosen, faktor selebihnya berposisi sebagai pendukung (Nasution 2001: 44).

Dari hasil penyebaran kuesioner yang dilakukan, hasil penelitian menunjukkan bahwa mahasiswa menginginkan dosen yang memiliki pengetahuan luas, pengalaman yang memadai, energetik atau semangat 
tinggi, serta konsentrasi yang tinggi sehinga dapat menjalankan pembelajaran secara efektif dan efisien seperti yang diimpikan mahasiswa. Metode pembelajaran yang digunakan juga sangat menentukan kejelasan dari pemaparan konsep, misalnya seorang dosen hanya menggunakan metode ceramah maka mahasiswa akan merasa bosan, cepat merasa ngantuk, dan mencari suatu hal yang sekiranya bisa membuat rasa bosan hilang seperti main handphone, berbicara di luar topik dengan mahasiswa yang lain, dan sibuk berfantasi dengan dunia khayalan. Hal tersebut akan berdampak pada rendahnya pemahaman mahasiswa terhadap materi, sehingga hasil belajar tidak sesuai yang diharapkan. Oleh karena itu, dosen harus mampu membuat mahasiswa hanya berfokus pada dosen, sehingga materi yang diajarkan cepat diterima dengan baik.

\section{Dosen Inspiratif}

Dosen yang ideal bukan hanya dosen yang "digugu atau ditiru" saja, akan tetapi tercermin dari tingkah lakunya yang selalu satu kata antara perkataan dan perbuatan. Selain itu diharapkan dosen mampu memberikan keteladanan pada teman sejawatnya dan mahasiswanya, kreatif, tidak sombong, dan rendah hati kepada sesama. Hal tersebut merupakan salah satu kriteria dosen yang diimpikan mahasiswa dalam arti lain yaitu dosen yang mampu menjadi inspirasi bagi mahasiswanya.
Dosen yang inspiratif adalah dosen yang melahirkan daya tarik dan spirit perubahan terhadap diri mahasiswa serta mampu mendesain pembelajaran yang inspiratif. Dosen inspiratif juga dapat diartikan sebagai dosen yang bisa memberikan penguatan berupa motivasi dan energi positif kepada mahasiswa.

Menurut pakar pendidikan $\mathrm{Hu}$ Wen Chiang yang dikutip dari Kompasiana (2017) tipe dosen yang paling ideal adalah dosen yang mampu menjadi inspirasi bagi mahasiswanya untuk maju. Inspirasi dari seorang dosen secara tidak langsung memiliki kekuatan yang mampu merubah pola pikir mahasiswa ke arah yang lebih baik.

Dosen inspiratif merupakan dosen yang sangat diimpikan oleh sebagian besar mahasiswa. Karena dosen yang inspiratif mampu memberikan pengaruh besar bagi kehidupan mahasiswa salah satunya dapat meningkatkan motivasi belajar mahasiswa. Emda (2017: 176) mengungkapkan bahwa fungsi motivasi yaitu sebagai pendorong usaha dalam mencapai prestasi, seseorang melakukan usaha harus mendorong keinginannya, dan menentukan arah perbuatannya kearah tujuan yang hendak dicapai. Dengan demikian seseorang dapat menyeleksi perbuatan untuk menentukan sesuatu yang harus dilakukan dalam rangka mencapai tujuan yang hendak dicapainya. 
Salah satu hal yang motivasi mahasiswa dan bersumber dari dosen yaitu pengalaman pendidikan ataupun pengalaman hidup dosen. Hal tersebut dapat menginspirasi mahasiswa untuk terpacu dan semangat dalam menjalani kehidupan khususnya menjadi mahasiswa yang lebih baik lagi. Selain itu, motivasi berupa reinforcement atau penguatan juga sangat dibutuhkan oleh mahasiswa agar tidak mudah down ketika menjalankan tugas sebagai mahasiswa.

\section{Memiliki Good Rapport.}

Salah satu kriteria dosen yang diimpikan oleh mahasiswa, yaitu dosen yang memiliki good rapport. Good rapport atau dalam istilah lain positive raport mengindikasikan hubungan yang baik berdampak positif bagi relasi pengajar dengan peserta didik. Sebagai seorang pengajar, salah satu tujuan penting membina rapport adalah untuk menciptakan atmosfer kelas di mana para peserta didik merasa nyaman dan berminat untuk belajar (Erawati 2016: 77-78; Supriatna, I. dkk, 2019).

Good rapport dengan mahasiswa merupakan suatu hal yang penting, karena bila dosen akrab dengan mahasiswa maka mahasiswa akan lebih mudah memahami materi perkuliahan. Hal ini disebabkan adanya budaya patriotisme di kalangan masyarakat Indonesia termasuk mahasiswa. Ini berarti di dalam proses perkuliahan kebanyakan mahasiswa menyukai dosen terlebih dahulu baru kemudian menyukai mata kuliah. Jadi jika dosen menginginkan mahasiswa menyukai mata kuliah yang diajarkan maka dosen yang bersangkutan harus terlebih dahulu membuat dirinya disukai oleh mahasiswa. Adapun karakter yang diinginkan responden/ mahasiswa dari dosen yang memiliki good rapport yaitu, dosen yang menyenangkan, ramah, mudah senyum, tidak cuek, dekat dengan mahasiswa, pengertian terhadap mahasiswa, dan humoris.

\section{Menerima Pendapat Mahasiswa}

Dosen dan mahasiswa merupakan komponen penting dalam sistem perkuliahan, keduanya sama-sama harus memenuhi kewajiban dalam pembelajaran. Mahasiswa sangat bergantung pada dosen, begitu juga sebaliknya. Hubungan antara kedua unsur ini sangatlah erat, terutama antara dosen pembimbing akademik dan mahasiswa bimbingan.

Pada tingkat akhir, kebanyakan mahasiswa mengalami masalah ketika mengerjakan tugas akhir (TA) atau yang disebut skripsi. Penyusunan skripsi adalah tahap ahir dalam mengemban pendidikan bagi mahasiswa dan syarat kelulusan bagi mahasiswa dan untuk mendapatkan gelar sarjana sesuai dengan bidang yang ditekuni. Skripsi menurut Hadi (Asmawan 2016: 51) sebagai karya ilmiah merupakan karya tulis yang dibuat berdasarkan pengetahuan- 
pengetahuan khusus dan fakta-fakta yang jelas.

Faktor yang menghambat mahasiswa dalam menyelesaikan skripsi ada dua faktor, yaitu faktor internal dan faktor eksternal. Faktor internal merupakan faktor dari dalam diri mahasiswa, sedangkan faktor internal adalah faktor yang berasal dari luar, seperti lingkungan, sistem perkuliahan, dan dosen pembimbing. Untuk itu dosen yang menerima pendapat dan mau membimbing mahasiswa dengan baik sangatlah diimpiimpikan, karena dengan komunikasi yang baik, saling memahami, saling mengerti maka penulisan skripsi akan cepat selesai dengan bimbingan dosen yang terbuka untuk mahasiswa.

Selanjutnya dosen yang menerima pendapat mahasiswa di dalam proses pembelajaran. Proses pembelajaran adalah proses yang di dalamnya terdapat kegiatan interaksi antara guru-siswa, dosenmahasiswa dan komunikasi timbal balik yang berlangsung dalam situasi edukatif untuk mencapai tujuan belajar (Rustaman, 2001: 461). Interaksi antara mahasiswa dengan dosen ketika proses pembelajaran berlangsung di dalam maupun di luar kelas sangatlah penting agar situasi dan kondisi dapat berjalan dengan baik dan efektif serta efisien. Tidak sedikit proses pmbelajaran berjalan dengan komunikasi satu arah yaitu hanya dosen yang berbicara, padahal proses pembelajaran merupakan komunikasi dua arah. Ketika proses pembelajaran sedang berlangsung, mahasiswa dituntut untuk bebas mengemukakan pendapat dan berpikir kritis, tetapi tidak jarang dosen yang tidak senang karena mahasiswanya mengemukakan pendapat yang kritis. Hal tersebut tampak pada ekspresi yang tidak menyenangkan ketika mahasiswa berpendapat dan dinilai tidak sejalan dengan pemikiran dosen.

Komunikasi sangat penting ketika proses pembelajaran berlangsung, dosen seharusnya menerima dan mengolah pendapat mahasiswa, serta menghargai usaha mahasiswa yang telah berusaha semaksimal mungkin untuk mengikuti proses pembelajaran dengan baik. Hal tersebut sejalan dengan kompetensi sosial yang harus dimiliki oleh setidaknya pendidik dalam hal ini dosen. Kompetensi sosial menurut UU no 14 yaitu kemampuan untuk berkomunikasi dan berintraksi secara efektif dan efisien dengan siswa, guru, orang tua/wali pesrta didik, dan masyarakat. Hal tersebut dapa diukur dari kemampuan dosen yang meliputi: 1) kemampuan menyampaikan pendapat; 2) kemampuan menerima kritik, saran, dan pendapat orang lain; 3) mengenal dengan baik mahasiswa yang mengikuti kuliahnya; 4) mudah bergaul di kalangan sejawat, karyawan, dan mahasiswa, 5) toleransi terhadap keberagaman mahasiswa. 


\section{Kesimpulan}

Berdasarkan hasil analisis data dan pembahasan yang telah diuraikan, maka dapat disimpulkan bahwa terdapat 7 kriteria dosen yang diimpikan mahasiswa diantaranya : (1) dosen yang terampil dalam melakukan penilan yaitu, dosen yang memberikan nilai secara objektif, tidak pelit nilai dan pengertian; (2) disiplin waktu, disiplin waktu ini mencakup ketepatan waktu masuk kelas, ketepatan waktu keluar kelas, ketepatan dalam jadwal perkuliahan, efektivitas pemanfaatan waktu untuk penyampaian materi kuliah dan lain sebagainya; (3) dosen yang menyenangkan, dalam artian dosen yang mampu menciptakan suasana atau pembelajaran yang menyenangkan; (4) dosen yang memiliki keterampilan mengajar, dalam artian menjelaskan konsep atau materi harus membuat mahasiswa cepat mengerti, tidak bertele-tele, singkat, padat, dan jelas; (5) dosen inspiratif, dalam artian dosen yang bisa menjadi sosok inspirasi bagi mahasiswa; (6) dosen yang memiliki good rapport, dalam artian dosen yang mampu membangun hubungan yang baik dengan mahasiswa; dan (7) dosen yang menerima pendapat mahasiswa.

\section{Daftar Pustaka}

Asmawan, M. Chairil. (2016). Analisis Kesulitan Mahasiswa Menyelesaikan Skripsi. Jurnal Pendidikan Ilmu Sosial, 26 (2), hal 51-57.

Emda, A. (2017). Kedudukan Motivasi Belajar Siswa dalam Pembelajaran. Lantanida Journal, 5 (2), hal. 93-196.
Erawati, M. (2016). Pembentukan Rapport di Kelas: Analisis Psikologi. PSIKOHUMANIORA: Jurnal Penelitian Psikologi. 1 (1), hal 75-94.

Jumwaniyah. (2018). Konsep Karakter Guru Menyenangkan Dalam Buku Genius Teaching: 9 Karakter Guru Menyenangkan Berbasis Ramah Otak Karya Rudiana Dan Relevansinya Terhadap Kompetensi Pedagogik Guru PAI. Skripsi: Universitas Islam Negeri Sunan Kalijaga.

Nasution, M. (2001). Hubungan Metode Mengajar Dosen, Keterampilan Belajar Sarana Belajar Dan Lingkungan Belajar Dengan Prestasi Belajar Mahasiswa. Jurnal Ilmu Pendidikan, 8 (1), hal 36-48.

Nurdin. (2013). Studi Etnografi : Etos Kerja Dosen STAIN Kendari. Jurnal AlIzzah, 8 (2), hal 210-233.

Rustaman, N. (2001). Ilmu dan Aplikasi Pendidikan. Bandung: Inperial Bakti Utama

Siswanto, B. (2005). Manajemen Tenaga Kerja Indonesia Pendekatan Administrarif dan Operasional. Jakarta: Bumi Aksara.

Slameto. (2015). Belajar dan Faktor-faktor yang Mempengaruhinya. Jakarta: Rineka Cipta.

Supriadi, Y. (2012). Pengaruh Karakter Guru (Kreatif, Humoris, dan Berwibawa) Terhadap Motivasi Belajar Siswa Pada Mata Pelajaran IPS Terpadu Di MTS Fatahillah Pangkalan Kecamatan Ciawigebang Kuningan. Skripsi: Institut Agama Islam Negeri (IAIN) Syekh Nurjati.

Supriatna, I., Asmahasanah, S., Rachmadtullah, R., \& Asdar, A. K. 
(2019, March). The effect of learning methods and self regulation on problem-solving ability of mathematics in elementary school. In Journal of Physics: Conference Series (Vol. 1175, No. 1, p. 012139). IOP Publishing.

Suryabrata, Sumadi. (2014). Psikologi Pendidikan. Jakarta: Rajawali Pers.

Syamsudin, Adin. (2007). Psikologi Kependidikan. Bandung: PT Remaja Rosda Karya. 